\title{
EFFECT OF ANTIOXIDANT TREATMENT ON SOME INDICATORS OF OBESITY-INDUCED CHANGES IN INSULIN SENSITIVITY AND BETA-CELL FUNCTION IN NEW ZEALAND WHITE RABBITS
}

\author{
ZH. IVANOVA ${ }^{1}$, G. PENCHEV ${ }^{2}$, S. RIBARSKI ${ }^{3}$, E. VACHKOVA ${ }^{1}$, N. GRIGOROVA ${ }^{1}$, \\ A. ROUSSENOV ${ }^{4}$, P. YONKOVA ${ }^{2}$, D. KOSTOV ${ }^{2}$, T. M. GEORGIEVA ${ }^{1}$, \\ A. MILANOVA ${ }^{1} \&$ I. PENCHEV GEORGIEV ${ }^{1}$ \\ ${ }^{1}$ Department of Pharmacology, Animal Physiology and Physiological Chemistry, \\ Faculty of Veterinary Medicine; ${ }^{2}$ Department of Veterinary Anatomy and Histology, \\ Faculty of Veterinary Medicine, ${ }^{3}$ Department of Morphology, Physiology and Ani- \\ mal Nutrition, Faculty of Agriculture; ${ }^{4}$ Department of Internal Diseases, Faculty of \\ Veterinary Medicine; Trakia University, Stara Zagora, Bulgaria
}

\begin{abstract}
Summary
Ivanova, Zh., G. Penchev, S. Ribarski, E. Vachkova, N. Grigorova, A. Roussenov, P. Yonkova, D. Kostov, T. M. Georgieva, A. Milanova \& I. Penchev Georgiev, 2015. Effect of antioxidant treatment on some indicators of obesity-induced changes in insulin sensitivity and beta-cell function in New Zealand white rabbits. Bulg. J. Vet. Med., 18, No 3, 194-208.

The current study was conducted to investigate the impact of dietary antioxidant supplementation on obesity-induced changes in some surrogate indices of insulin sensitivity and B-cell function in New Zealand white rabbits. Three groups of rabbits were used in this experiment: castrated animals treated with antioxidants (vitamin $\mathrm{E}$ and d-limonene, Immunoprotect) $(\mathrm{Cim} ; \mathrm{n}=6)$, castrated obese animals $(\mathrm{CO} ; \mathrm{n}=6)$ and non-castrated non-obese controls $(\mathrm{NC} ; \mathrm{n}=7)$. At the end of the follow-up period of 2 months after castration an intravenous glucose tolerance test (IVGTT) was performed after 12-hour fasting. Blood samples for determination of simplified estimates of insulin resistance and $\beta$-cell function were obtained at baseline and at various time intervals over the 120-min test. In addition, lipid content in $m$. Longissimus lumborum и $m$. Semimembranosus was determined. Some of the simplified measurements of insulin resistance (fasting insulin, fasting insulin to glucose ratio, $\mathrm{HOMA}_{\text {ins.resist }}$ index), beta-cell function $\left(\mathrm{HOMA}_{\beta-\text { cell }}, \mathrm{AUC}_{\text {insulin } 0 \rightarrow 60 \mathrm{~min}}\right)$ and muscles lipid content in $\mathrm{CO}$ were higher while QUICKI and Bennett indices were lower than in controls. No differences in surrogate indices between $\mathrm{CIm}$ and $\mathrm{NC}$ groups were found suggesting improvement of insulin sensitivity and $\beta$-cell function after antioxidant supplementation. Surrogate indices are simple and reliable indicators of insulin sensitivity and $\beta$-cell function in rabbits as they were closely associated with markers of obesity and can be modified by antioxidant supplementation.
\end{abstract}

Key words: antioxidant supplementation, insulin resistance and $\beta$-cell function indices, obesity, rabbits 


\section{INTRODUCTION}

Decreased insulin sensitivity, termed insulin resistance (IR), can in part be defined as a reduced ability of insulin to activate glucose uptake and intracellular metabolism in target tissue (Saltiel, 2001; Gerich, 2003; Kahn, 2003; Weiss, 2007; Dimitrova \& Georgiev, 2007). Reduced insulin action in skeletal muscle, is the primary defect responsible for the development of hyperglycaemia which is the hallmark of the impaired glucose tolerance and type 2 diabetes (Henriksen \& Dokken, 2006; Corcoran et al., 2007; DeFronzo \& Tripathy, 2009; Samuel et al., 2010). Despite extensive investigations, showing inverse association between the increased intramuscular lipid content and insulin sensitivity, the underlying molecular underpinnings of lipidinduced insulin resistance in skeletal muscle remains unclear (Morino et al., 2006; Haugaard et al., 2009; Henriksen, 2010; Muoio, 2010; Martins et al., 2012).

An emerging body of evidence revealed the importance of defects in $\beta$-cell function and insulin secretion for the impairment of glucose homeostasis in obesity and/or type 2 diabetes (Festa et al., 2008; Poitout \& Robertson, 2008; Giacca et al., 2010). Although it is generally accepted that the risk of developing diabetes is determined by the combination of genetic susceptibility of the $\beta$-cells and damaging effects of hyperglycaemia and/or hyperlipidaemia, termed glucolipotoxicity, the mechanisms involved in $\beta$-cell failure are largely unknown (Lu et al., 2010).

Several insulin sensitivity indices - homeostasis model assessment (HOMA ins.res. $_{\text {. }}$, quantitative insulin sensitivity check index (QUICKI), insulin sensitivity index (ISI) and $\beta$-cell function $-\mathrm{HOMA}_{\beta \text {-cell }}$, insulinogenic index, acute phase of insulin sec- retion (AIR) are used in humans (Tripathy et al., 2004; Chen et al., 2005; Festa et al., 2008; Martinez-Hervas et al., 2011), dogs (Irvine et al., 2002; Larson et al., 2003) and cats (Appleton et al., 2005) but so far not in rabbits. At the same time, many features of lipoprotein metabolism in rabbits are similar to those in humans (so-called LDL mammals) but differ from the most widely used experimental animals - rats and mice, which are predominantly HDL animals (Kitajima et al., 2004; Zheng et al., 2009; Waqar et al., 2010). That is why rabbits are increasingly used as appropriate animal models to study pathogenic mechanisms of obesityassociated abnormalities in lipid and glucose metabolism such as insulin resistance, dyslipidaemia, atherosclerosis, metabolic syndrome and type 2 diabetes (Kainuma et al., 2006; Kawai et al., 2006; Zhao et al., 2007; Waqar et al., 2010). Therefore, there is an increasing need to apply simple and reliable markers for evaluation of insulin sensitivity and $\beta$-cell function in rabbits.

Obesity has been described as a state of chronic inflammation, associated with oxidative stress which seems to play an important pathogenic role in the vicious cycle linking obesity, insulin resistance and type 2 diabetes (Franzini et al., 2008; Roberts \& Sindhu, 2009; Valdecantos et al., 2009; Lin et al., 2012). Furthermore, reactive oxygen species (ROS) have been defined as an initial key factor triggering obesity-induced insulin resistance as their increased generation preceded the elevation of tumour necrosis factor-alpha (TNF$\alpha$ ) and free fatty acids (FFA) in the plasma and liver (Matsuzawa-Nagata et al., 2008). However, despite the well documented negative impact of ROS on insulin action and insulin secretion, the evidence for a 
beneficial effect of exogenous antioxidants is inconsistent because many interventional studies yield conflicting results. (Davis et al., 2002; Houstis et al., 2006; Franzini et al., 2008; Singh et al., 2008; Bashan et al., 2009). In addition, the impact of antioxidants on insulin resistance and $\beta$-cell dysfunction in most trials is too weak, hence, further studies are required in order to better understand the effects of dietary antioxidants on obesity-associated disorders (Opara, 2004; Bashan et al., 2009; Boudina et al., 2012; Garcia-Diaz et al., 2012).

Recently, our laboratory created an animal model, using castrated male New Zealand white rabbits and reported that 2 months after castration rabbits developed visceral obesity, dyslipidaemia and impaired glucose tolerance (Georgiev et al., 2011). Antioxidant (vitamin E and d-limonene) treatments affected favourably blood lipid profile and glucose kinetics (Georgiev et al., 2009; 2011). In addition, we established reference ranges of some glucose kinetic parameters during intravenous glucose tolerance test (IVGTT) in lean rabbits (Dimitrova et al., 2008).

The current study was conducted to investigate the impact of dietary antioxidant supplementation on the obesity-induced changes in some indices of insulin sensitivity and $\beta$-cell function in $\mathrm{New}$ Zealand white rabbits.

\section{MATERIALS AND METHODS}

\section{Experimental design and experimental procedures}

The model of visceral obesity was created by castration of male New Zealand white rabbits as previously described (Georgiev et al., 2009; 2011). The experimental procedure was approved by the Commission of Ethics at the Faculty of Veterinary Me- dicine of Trakia University, Stara Zagora. During the entire experimental period the recommendations for caring and treatment of rabbits reared as experimental animals were followed.

The design of the experiment has already been reported in details (Georgiev et al., 2011). Briefly, 2-2.5 month-old rabbits were randomly divided into 3 groups: i) first group (CIm; $n=6$ ) - castrated obese and treated with Immunoprotect for 2 months; ii) second group ( $\mathrm{CO} ; \mathrm{n}=6$ ) - castrated obese; and iii) third group $(\mathrm{NC} ; \mathrm{n}=7)$ - control group, non-castrated non-obese. Imunoprotect is an oily nutritional supplement. It contains two antioxidants: vitamin $\mathrm{E}$ (10 $\mathrm{mg}$ equivalent to $15 \mathrm{IU}$ ) and organic extract from citrus fruits peel $(90 \mathrm{mg})$, which contains in high proportion d-limonene. Imunoprotect was produced and provided by Pharmaray, Sofia, Bulgaria as gelatinous capsules. The rabbits from the first group received two capsules per os daily before the morning feeding for 2 months.

At the end of the follow-up 2-month period after castration an intravenous glucose tolerance test (IVGTT) was performed after 12-hour fasting (Liu et al., 2005; Zhao et al., 2007; Georgiev et al., 2011). Blood samples for determination of simplified measurements of insulin resistance and $\beta$-cell function were obtained at baseline and at various time over the 120-min duration of the test.

Blood samples for the determination of insulin and glucose concentrations were collected from the jugular veins. Heparin was used as anticoagulant to obtain plasma for the insulin assay. The blood samples were centrifuged immediately after the collection at $800 \times g$ for $15 \mathrm{~min}$. The plasma was stored in plastic tubes at $-20{ }^{0} \mathrm{C}$ until assayed. Glucose concentration was measured in whole blood. 


\section{Laboratory methods}

Plasma insulin concentration was measured by radioimmunoassay with a commercially available kit adapted for rabbits (Immunotech, Prague, Czech Republic). The blood glucose concentration was measured immediately after collection of the samples with a glucosemeter (Home Diagnostics, Inc., Ft. Lauderdale, Florida, USA) based on glucose oxidase method using one drop of whole blood.

Lipid content in muscle samples was determined after extraction with chloroform/methanol as described (Gondret et al., 2004). Muscle lipid content was expressed as $\mathrm{g}$ per $100 \mathrm{~g}$ fresh tissue.

\section{Indices of insulin sensitivity}

The surrogate indices of insulin sensitivity were calculated as described in cats (Appleton et al., 2005). The following parameters were determined: fasting insulin (Io), fasting insulin to glucose (Go) ratio (Io/Go), insulin concentration at $60^{\text {th }}$ and $120^{\text {th }}$ min $\left(\mathrm{I}_{60} \min\right.$ and $\left.\mathrm{I}_{120} \mathrm{~min}\right)$ and insulin to glucose ratio at $60^{\text {th }}$ and $120^{\text {th }} \mathrm{min}$. after glucose infusion.

Some simplified insulin sensitivity estimates $\left(\mathrm{HOMA}_{\text {ins. res., }}\right.$ QUICKI and the Bennett index) were calculated from insulin and glucose values at baseline using the following equations:

1) $\mathrm{HOMA}_{\text {ins. res. }}=\left(\mathrm{I}_{0} \times \mathrm{G}_{0}\right) / 22.56$ (Mattheeuws et al., 1984; Wallace et al., 2004; Chen et al., 2005);

2) $\mathrm{QUICKI}=1 /\left[\log \mathrm{I}_{0}+\log \mathrm{G}_{0}\right]$ (Wallace et al., 2004; Appleton et al., 2005; Chen et al., 2005);

3) Bennett index $=1 / \log \mathrm{I}_{0} \times \log \mathrm{G}_{0}$ (Appleton et al., 2005; Ciampelli et al., 2005);

where: $I_{0}$ is the fasting insulin $(\mu \mathrm{U} / \mathrm{mL})$ and $\mathrm{G}_{0}$ is the fasting glucose $(\mathrm{mmol} / \mathrm{L})$. Higher HOMA $\mathrm{Ans}_{\text {ins. res. }}$ and lower QUICKI and Bennett indices are indicators of increased insulin resistance.

\section{Indices of $\beta$-cell function}

$\mathrm{HOMA}_{\beta \text {-cell }}$ was calculated using the equation:

$\mathrm{HOMA}_{\beta \text {-cell }}=\left(20 \times \mathrm{I}_{0}\right) /\left(\mathrm{G}_{0}-3.5\right)$ (Mattheeuws et al., 1984; Wallace et al., 2004).

The indices characterising the first or early phase of insulin secretion and insulin secretion during the $1^{\text {st }}$ and $2^{\text {nd }}$ hours after glucose loading during IVGTT were calculated as shown in dogs (Irvine et al., 2002; Larson et al., 2003; Slavov et al., 2010). The highest values of insulin and glucose were considered peak values and the increments of insulin and glucose concentration above their respective fasting levels were considered as $\Delta \mathrm{I}$ and $\Delta \mathrm{G}$ (Larson et al., 2003). Early phase insulin secretion in response to glucose infusion was calculated as the insulinogenic index $(\Delta \mathrm{I} / \Delta \mathrm{G})$, the area under the curve for insulin was determined from 0 to $10 \mathrm{~min}\left(\mathrm{AUC}_{\text {insulin } 0 \rightarrow 10 \mathrm{~min}}\right)$ and insulin to glucose ratio - by the $10^{\text {th }} \mathrm{min}$ $\left(\mathrm{I}_{10 \mathrm{~min}} / \mathrm{G}_{10}\right.$ min $)$ (Larson et al., 2003). Insulin secretions during the $1^{\text {st }}$ and $2^{\text {nd }}$ hour after IVGTT were calculated as $\mathrm{AUC}_{\text {insulin } 0 \rightarrow 60 \text { min }}$ and $\mathrm{AUC}_{\text {insulin } 60 \rightarrow 120 \text { min }}$ respectively (Larson et al., 2003; Slavov et al., 2010).

\section{Histological examination}

At the end of the experiment ( 2 months after castration) 3 rabbits from each group were sacrificed by an overdose of thiopental sodium. Material for histological examination was taken from $m$. Longissimus lumborum (LL). The obtained tissue specimens were fixed in Bouin's fixative and in 10\% neutral-buffered formalin. After fixation the tissue specimens were embedded in paraffin, cut into $6 \mu \mathrm{m}$ thick sections and stained with 
Effect of antioxidant treatment on some indicators of obesity-induced changes in insulin sensitivity ...

haematoxylin and eosin. In addition, tissue samples for determination of lipid content were obtained from $m$. Longissimus lumborum and $m$. Semimembranosus (SMB). The results for markers of obesity (body weight - BW, body mass index - BMI, amount of visceral fat), lipid profile (plasma triglycerides, total cholesterol, high- and low-density lipoprotein cholesterol concentrations) and some IVGTT parameters $\left(\mathrm{K}_{\mathrm{el}}\right.$ glucose, $\mathrm{AUC}_{\text {glucose }}$ $0 \rightarrow 120$ min, $\mathrm{AUC}_{\text {insulin } 0 \rightarrow 120 \mathrm{~min}}$ and $\mathrm{AUC}_{\text {insulin }}$ $0 \rightarrow 120 \mathrm{~min} / \mathrm{AUC}_{\text {glucose }} 0 \rightarrow 120 \mathrm{~min}$ ratio) are published elsewhere (Georgiev et al., 2011).

\section{Statistical analysis}

Statistical analyses were performed using Statistica v.6.1 for Windows (StatSoft Ins., USA, 1984-2002). All data are presented as means \pm standard error of the mean (mean \pm SEM) calculated according to standard descriptive statistical tests. The ANOVA was used to evaluate the significance of the differences in the quantitative variables (concentrations of insulin, surrogate indices of insulin resistance and $\beta$-cell function and skeletal muscle lipid and glycogen contents) between the three experimental animal groups. When the group effect was significant, the differences between groups were determined by the post hoc LSD test. Correlations between markers of obesity and calculated parameters of insulin sensitivity and $\beta$-cell function were determined, using the Pearson correlation analysis at a level of significance $\mathrm{P}<0.05$.

\section{RESULTS}

\section{Indices of insulin sensitivity}

The mean values of insulin sensitivity indices are presented in Table 1. Basal insulin concentrations and their respective insulin to glucose ratios in $\mathrm{CO}$ were significantly $(\mathrm{P}<0.01)$ higher than in $\mathrm{CIm}$ and control (NC) groups. Insulin concentrations at min 120 did not differ between groups while insulin concentration at min 60 in $\mathrm{CO}$ was significantly $(\mathrm{P}<0.05)$ higher than in CIm. Mean insulin to

Table 1. Surrogate indices of insulin sensitivity $(\mathrm{Mean} \pm \mathrm{SEM})$ in the three groups of rabbits: castrated, obese, and treated with Immunoprotect (CIm group; $n=6$ ); castrated-obese (CO group; $\mathrm{n}=6$ ) and non-castrated, non-obese (control) rabbits ( $\mathrm{NC}$ group; $\mathrm{n}=7$ )

\begin{tabular}{|c|c|c|c|c|}
\hline $\begin{array}{l}\text { Indices of insulin } \\
\text { sensitivity }\end{array}$ & Abbreviations & CIm group & $\mathrm{CO}$ group & $\mathrm{NC}$ group \\
\hline Basal insulin $(\mu \mathrm{U} / \mathrm{mL}) *$ & $\mathrm{I}_{0}$ & $1.70 \pm 0.25^{\mathrm{b}}$ & $11.0 \pm 2.73^{\mathrm{a}}$ & $2.90 \pm 0.94^{b}$ \\
\hline $\begin{array}{l}\text { Basal insulin to } \\
\text { glucose ratio* }\end{array}$ & $\mathrm{I}_{0} / \mathrm{G}_{0}$ & $0.34 \pm 0.06^{\mathrm{b}}$ & $2.20 \pm 0.44^{\mathrm{a}}$ & $0.74 \pm 0.26^{\mathrm{b}}$ \\
\hline $\begin{array}{l}\text { Insulin after glucose } \\
\text { injection }(\mu \mathrm{U} / \mathrm{mL})^{*}\end{array}$ & $\begin{array}{l}\mathrm{I}_{60 \min } \\
\mathrm{I}_{120 \mathrm{~min}}\end{array}$ & $\begin{array}{l}1.80 \pm 0.65^{\mathrm{b}} \\
1.30 \pm 0.37\end{array}$ & $\begin{array}{l}7.80 \pm 3.06^{\mathrm{a}} \\
5.80 \pm 2.98\end{array}$ & $\begin{array}{l}3.40 \pm 1.26 \\
2.80 \pm 0.48\end{array}$ \\
\hline $\begin{array}{l}\text { Insulin/glucose ratio } \\
\text { after glucose injection* }\end{array}$ & $\begin{array}{l}\mathrm{I}_{60 \mathrm{~min}} / \mathrm{G}_{60 \mathrm{~min}} \\
\mathrm{I}_{120 \mathrm{~min}} / \mathrm{G}_{120 \mathrm{~min}}\end{array}$ & $\begin{array}{l}0.29 \pm 0.9 \\
0.21 \pm 0.42\end{array}$ & $\begin{array}{l}1.67 \pm 0.86 \\
1.39 \pm 0.81\end{array}$ & $\begin{array}{l}0.80 \pm 0.31 \\
0.58 \pm 0.09\end{array}$ \\
\hline $\mathrm{HOMA}_{\text {ins. resist. index }}{ }^{*}$ & & $0.40 \pm 0.08^{\mathrm{b}}$ & $2.16 \pm 0.69^{\mathrm{a}}$ & $0.48 \pm 0.1^{\mathrm{b}}$ \\
\hline QUICKI index** & & $1.24 \pm 0.23^{\mathrm{b}}$ & $0.73 \pm 0.13^{\mathrm{a}}$ & $1.23 \pm 0.19^{b}$ \\
\hline Bennett index** & & $7.04 \pm 1.59^{b}$ & $1.62 \pm 0.26^{\mathrm{a}}$ & $4.98 \pm 1.37^{b}$ \\
\hline
\end{tabular}

*The higher the value, the lower the insulin sensitivity; **The lower the value, the lower the insulin sensitivity. Means with different superscripts within the same row differ at $\mathrm{P}<0.05$. 
Table 2. Surrogate indices of beta-cell function (Mean \pm SEM) in the three groups of rabbits: castrated, obese, and treated with Immunoprotect ( $\mathrm{CIm}$ group; $\mathrm{n}=6$ ); castrated-obese (CO group; $\mathrm{n}=6$ ) and non-castrated, non-obese (control) rabbits ( $\mathrm{NC}$ group; $\mathrm{n}=7$ )

\begin{tabular}{|c|c|c|c|c|}
\hline $\begin{array}{l}\text { Indices of beta-cell } \\
\text { function }\end{array}$ & Abbreviations & CIm group & CO group & NC group \\
\hline Insulinogenic index & $\Delta \mathrm{I} / \Delta \mathrm{G}$ & $4.9 \pm 1.8$ & $5.6 \pm 2.73$ & $5.31 \pm 0.49$ \\
\hline Insulin to glucose ratio & $\mathrm{I}_{10 \mathrm{~min}} / \mathrm{G}_{10 \min }$ & $3.6 \pm 1.35$ & $4.5 \pm 1.8$ & $3.9 \pm 0.42$ \\
\hline HOMA $\beta$ cell & & $39.8 \pm 16.9^{b}$ & $153.7 \pm 32.2^{\mathrm{a}}$ & $29.3 \pm 7.2^{\mathrm{b}}$ \\
\hline $\begin{array}{l}\text { Area under the insulin } \\
\text { curve } 0 \rightarrow 10 \mathrm{~min} \\
(\mu \mathrm{U} / \mathrm{mL} \times \min )\end{array}$ & $\mathrm{AUC}_{\text {ins } 0 \rightarrow 10 \mathrm{~min}}$ & $149.3 \pm 49$ & $210.9 \pm 71$ & $145.5 \pm 17$ \\
\hline $\begin{array}{l}\text { Area under the insulin } \\
\text { curve } 0 \rightarrow 60 \mathrm{~min} \\
(\mu \mathrm{U} / \mathrm{mL} \times \mathrm{min})\end{array}$ & $\mathrm{AUC}_{\text {ins } 0 \rightarrow 60 \mathrm{~min}}$ & $106.0 \pm 22^{\mathrm{b}}$ & $564.0 \pm 118^{a}$ & $190.3 \pm 57^{b}$ \\
\hline $\begin{array}{l}\text { Area under the insulin } \\
\text { curve } 60 \rightarrow 120 \mathrm{~min} \\
(\mu \mathrm{U} / \mathrm{mL} \times \min )\end{array}$ & $\mathrm{AUC}_{\text {ins } 60 \rightarrow 120 \mathrm{~min}}$ & $95.0 \pm 30$ & $407.5 \pm 174$ & $201.0 \pm 51$ \\
\hline
\end{tabular}

Means with different superscripts within the same row differ at $\mathrm{P}<0.05$.

glucose ratios at min 60 and 120 in $\mathrm{CO}$ rabbits tended to be higher $(\mathrm{P}<0.1)$ than those in the Cim groups, while there were no differences between both groups of castrated rabbits (CO and CIm) vs control group $(\mathrm{NC})$. $\mathrm{HOMA}_{\text {ins.resist }}$ values in $\mathrm{CO}$ were significantly $(\mathrm{P}<0.01)$ higher than both control (NC) and CIm groups. In contrast, QUICKI and Bennett indices in CO were substantially $(\mathrm{P}<0.05)$ lower than in control and Cim rabbits. Meanwhile, no differences in $\mathrm{HOMA}_{\text {ins.resist. }}$ QUICKI and Bennett indices were found between control rabbits and those treated with Immunoprotect (Table 1).

\section{Indices of $\beta$-cell function}

The mean values of beta-cell function indices are presented in Table 2 .

$\mathrm{HOMA}_{\beta}$ cell index in CO was significantly $(\mathrm{P}<0.001)$ higher than in $\mathrm{NC}$ and CIm. There were no differences in the indices, characterising the first (early) phase of insulin secretion in response to exogenous glucose loading during IVGTT $\left(\Delta \mathrm{I} / \Delta \mathrm{G}, \mathrm{I}_{10 \mathrm{~min}} / \mathrm{G}_{10 \mathrm{~min}}\right.$ and $\left.\mathrm{AUC}_{\text {insulin } 0 \rightarrow 10 \mathrm{~min}}\right)$. Insulin secretion during the $1^{\text {st }}$ hour after glucose infusion ( $\mathrm{AUC}_{\text {insulin } 0 \rightarrow 60 \mathrm{~min}}$ ) in $\mathrm{CO}$ was considerably $(\mathrm{P}<0.01)$ higher than in $\mathrm{NC}$ and Cim groups. During the $2^{\text {nd }}$ hour after glucose infusion ( $\mathrm{AUC}_{\text {insulin } 60 \rightarrow 120 \mathrm{~min}}$ ) insulin secretion in $\mathrm{CO}$ was also higher than in NC and CIm although not significantly.

\section{Chemical composition of skeletal muscles}

Mean concentrations of lipids in $m$. Longissimis lumborum (LL) and $m$. Semimembranosus (SBM) are presented on Fig. 1. Lipid SMB content in noncastrated non-obese rabbits (controls) tended to be higher than that of LL, while two months after castration it increased more markedly in LL muscle (Fig. 1). Lipid content of LL muscle in castrated obese rabbits was significantly greater than both controls $(\mathrm{P}<0.001)$ and castrated, obese animals supplemented with 


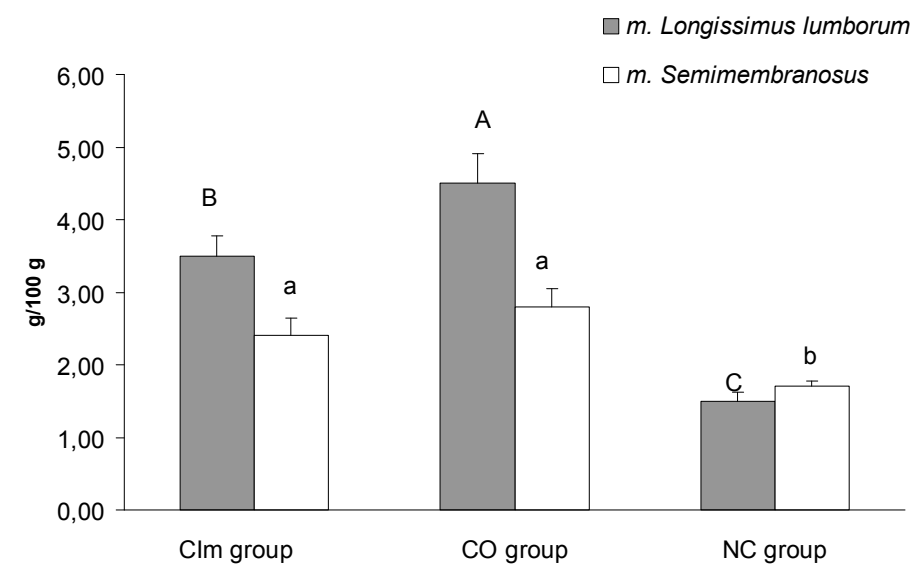

Fig. 1. Lipid content (g/100 g) of $m$. Longissimus lumborum and $m$. Semimembranosusin castrated obese rabbits treated with antioxidants (Cim group), castrated obese rabbits (CO group) and noncastrated non-obese rabbits (NC group) Different capital letters show statistically significant differences between groups with respect to m. Longissimus lumborum; while different lower case letters - significant differences between groups for m. Semimembranosus.

Immunoprotect $(\mathrm{P}<0.05)$. Lipid $\mathrm{SMB}$ content in castrated rabbits from $\mathrm{CO}$ and CIm groups was significantly $(\mathrm{P}<0.01)$ higher than in non-castrated non-obese (NC) animals (Fig. 1).

\section{Histological examination}

Light microscopy of muscle samples revealed increased fat deposition in LL muscle of rabbits from the $\mathrm{CO}$ group (Fig. 2). In the CIm group, a lower fat content in muscle samples was detected, while in non-castrated non-obese (control) rabbits no adipocytes were observed. In all samples, the adipose tissue was predominantly located in the perimysium.

\section{Correlation analysis}

Basal insulin correlated significantly positively with $\mathrm{HOMA}_{\text {ins. resist. }}(\mathrm{r}=0.94$; $\mathrm{P}<0.001), \mathrm{HOMA}_{\beta}$ cell $(\mathrm{r}=0.63 ; \mathrm{P}<0.01)$, triglycerides $\quad(\mathrm{r}=0.77 ; \quad \mathrm{P}<0.01) \quad$ and $\mathrm{AUC}_{\text {insulin }} 0 \rightarrow 60 \min (\mathrm{r}=0.66 ; \mathrm{P}<0.01)$ and tended to correlate with the amount of visceral fat $(\mathrm{r}=0.41 ; \mathrm{P}<0.1) . \quad \mathrm{HOMA}_{\text {ins. }}$ resist. correlated significantly positively with $\mathrm{BW}(\mathrm{r}=0.55 ; \mathrm{P}<0.05)$, triglycerides $(\mathrm{r}=0.73 ; \quad \mathrm{P}<0.01), \quad \mathrm{AUC}_{\text {insulin }} \quad 0 \rightarrow 60 \quad \mathrm{~min}$ $(\mathrm{r}=0.81 ; \mathrm{P}<0.01)$ and $\mathrm{AUC}_{\text {insulin }} 60 \rightarrow 120 \mathrm{~min}$ $(\mathrm{r}=0.81 ; \mathrm{P}<0.01)$ and tended to correlate with amount of visceral fat $(\mathrm{r}=0.40$; $\mathrm{P}<0.1)$. The Bennett index correlated significantly negatively with basal insulin $(\mathrm{r}=0.71 ; \mathrm{P}<0.01)$, HOMA ins. resist. $(\mathrm{r}=$ $-0.67 ; \quad \mathrm{P}<0.01)$, triglycerides $(\mathrm{r}=-0.79$; $\mathrm{P}<0.01), \mathrm{I}_{0} / \mathrm{G}_{0} \quad(\mathrm{r}=0.72 ; \mathrm{P}<0.01)$ in $m$. SMB $\quad(\mathrm{r}=0.64 ; \quad \mathrm{P}<0.01) . \quad \mathrm{I}_{0} / \mathrm{G}_{0} \quad$ ratio correlated significantly positively with triglycerides $\quad(\mathrm{r}=0.80 ; \quad \mathrm{P}<0.01) \quad$ and HOMA $_{\text {ins. }} \quad$ resist. $\quad(\mathrm{r}=0.93 ; \quad \mathrm{P}<0.001)$. $\mathrm{HOMA}_{\beta}$ cell correlated significantly positively with triglycerides $(\mathrm{r}=0.72 ; \mathrm{P}<0.01)$, $\mathrm{AUC}_{\text {insulin }} 0 \rightarrow 60$ min $(\mathrm{r}=0.64 ; \mathrm{P}<0.01)$ in SMB $(r=0.65 ; \mathrm{P}<0.01)$.

Lipid concentration in SMB correlated significantly positively with $\mathrm{BW}(\mathrm{r}=0.48$; $\mathrm{P}<0.05)$ and visceral fat $(\mathrm{r}=0.48 ; \mathrm{P}<0.05)$ and tended to correlate negatively with 
$\mathrm{K}_{\text {el glucose }}(\mathrm{r}=-0.41 ; \mathrm{P}<0.1)$. Lipid concentration of LL correlated significantly positively with $\mathrm{AUC}_{\text {insulin }} 0 \rightarrow 60$ min $(\mathrm{r}=0.62$; $\mathrm{P}<0.01)$ and visceral fat amount $(\mathrm{r}=0.61$; $\mathrm{P}<0.01)$.
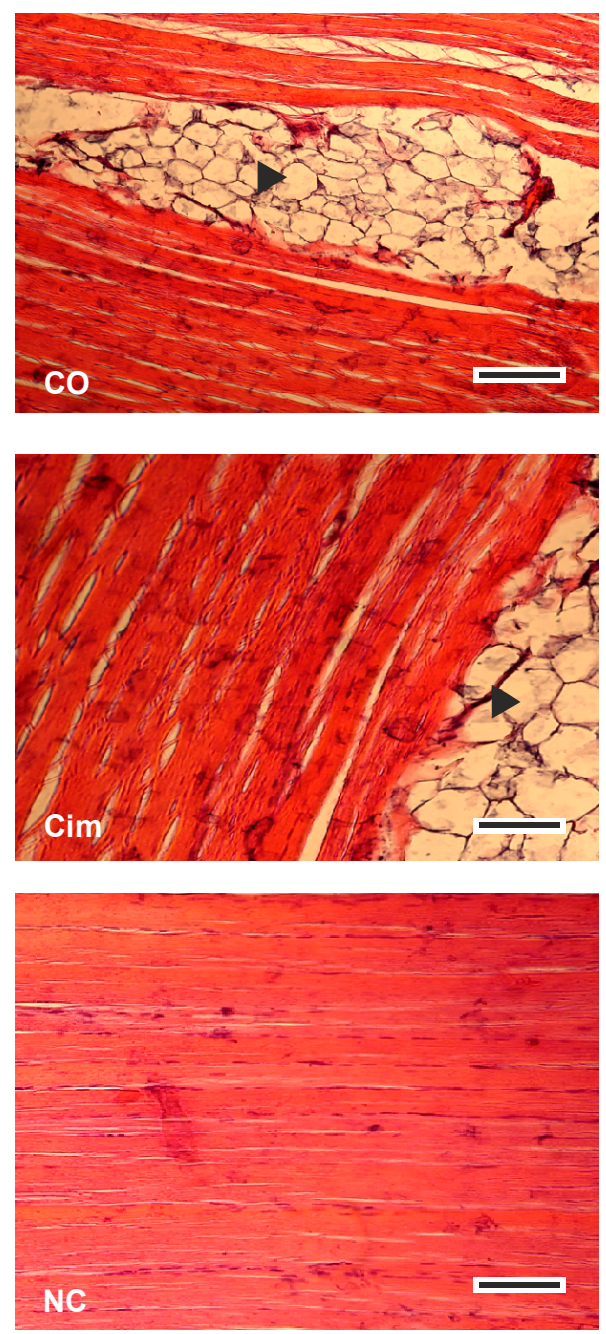

Fig. 2. Longitudinal section of skeletal muscle in castrated obese rabbits (CO), castrated and treated with Immunoprotect rabbits (Cim) and non-castrated rabbits (NC); arrowheads - adipose tissue; $\mathrm{H} / \mathrm{E}$; bar $=50 \mu \mathrm{m}$.
There was a strong positive correlation of insulinogenic index $(\Delta \mathrm{I} / \Delta \mathrm{G})$ with $\mathrm{AUC}_{\text {insulin } 0 \rightarrow 10 \text { min }}(\mathrm{r}=0.98 ; \mathrm{P}<0.001)$ and $\mathrm{I}_{10 \mathrm{~min}} / \mathrm{G}_{10 \min }(\mathrm{r}=0.99 ; \mathrm{P}<0.001)$.

\section{DISCUSSION}

The visceral or central obesity in humans is the main predisposing factor for various metabolic abnormalities such as insulin resistance, metabolic syndrome, type 2 diabetes and cardiovascular diseases (Lewis et al., 2002; Ibrahim, 2010; Galic et al., 2010; Slavov \& Dzelebov, 2010). A growing number of studies show that obesity-associated systemic and/or organspecific oxidative stress is a crucial factor involved in the impairment of insulin sensitivity and B-cell function (Dokken et al., 2008; Poitout \& Robertson, 2008; Bashan et al., 2009; Valdecantos et al., 2009). The use of some simple and reliable indicators of insulin resistance and $\beta$-cell function will be advantageous over the "gold standard" hyperinsulinaemic euglycaemic clamp, which is complicated, labour intensive and time demanding procedure (Chen et al., 2005; Muniyappa et al., 2009).

Recently we found that high-fat feeding-induced obesity in dogs is associated with marked impairment of insulin sensitivity and $\beta$-cell function (Slavov et al., 2010). In the current study we demonstrated that basal insulin concentration, $\mathrm{HOMA}_{\text {ins }}$ res, $\mathrm{I}_{0} / \mathrm{G}_{0}$ ratio, $\mathrm{HOMA}_{\beta}$ cell, $\mathrm{AUC}_{\text {insulin }} 0-60 \mathrm{~min}$ and intramuscular lipid content in castrated obese rabbits were significantly higher while QUCKI and Bennett indices were significantly lower than in non-castrated non-obese rabbits and correlated with the markers of obesity. Antioxidant supplementation favourably modified surrogate indices of insulin sensitivity and $\beta$-cell function. 
Effect of antioxidant treatment on some indicators of obesity-induced changes in insulin sensitivity ...

Our results indicated a marked hyperinsulinaemia at baseline in castrated-obese rabbits which is consistent with other data in obese rabbits (Kawai et al., 2006; Zheng et al., 2009). Obesity-induced fasting hyperinsulinaemia has been also described in cats (Thiess et al., 2004; Appleton et al., 2005), dogs (Verkest et al., 2005; Verkest et al., 2011) and humans (Festa et al., 2008; DeFronzo \& Tripathy, 2009; Gil-Campos et al., 2010). In addition, we found significantly higher values of fasting insulin to glucose ratio, $\mathrm{HOMA}_{\text {ins. resist }}$ and $\mathrm{HOMA}_{\beta \text {-cell }}$ and significantly lower QUICKI and Bennett indices in obese than in lean rabbits. Similar obesity-induced changes of surrogate insulin estimates were described in cats (Appleton et al., 2005). Basal insulin and $\mathrm{HOMA}_{\text {ins. }}$ resist., were positively correlated with body weight, the amount of intraabdominal fat and plasma triglycerides, showing that hyperinsulinaemia in castrated rabbits was closely associated with visceral obesity. Usually, during the early stage of insulin resistance, $\beta$-cell function and insulin secretion are increased to maintain normoglycaemia in the face of decreased sensitivity and/or responsiveness of target tissues to insulin (Bergman et al., 2002; Weir \& BonnerWeir, 2004). This is further confirmed by the significant positive correlation between muscle lipid content and $\mathrm{AUC}_{\text {ins }} 0 \rightarrow 60$ min.

The strong correlation between $\mathrm{HOMA}_{\text {ins. resist }}$ and basal plasma insulin in our study indicates that measurement of plasma insulin in rabbits with food withheld for $12 \mathrm{~h}$ could be used in research settings as a reliable predictor of insulin resistance.

In humans, Weir \& Bonner-Weir (2004) propose five stages of evolving $\beta$ cell dysfunction during progression to diabetes, each of them being characterised by corresponding changes in insulin secretion and insulin sensitivity: compensation, $\beta$-cell adaptation, early decompensation, stable decompensation and severe decompensation. The progressive $\beta$-cell failure is closely associated with oxidative stress as the expression levels of antioxidant enzymes in $\beta$-cells are very low (Robertson, 2004; Kaneto et al., 2005; Prentki \& Nolan, 2006). Accordingly, chronically excessive levels of reactive oxygen species are shown to cause decreased insulin gene expression and accelerated rates of $\beta$-cell apoptosis (Robertson, 2004). Taking into account the proposed stages of $\beta$-cell dysfunction in humans, our results show that two months after castration obese rabbits are in the stage of compensation as they exhibited marked hyperinsulinaemia, higher $\mathrm{HOMA}_{\beta \text {-cell, higher insulin secre- }}$ tion rate during the first hour after glucose infusion $\left(\mathrm{AUC}_{\text {insulin } 0 \rightarrow 60 \mathrm{~min}}\right)$.

We found no group differences in the insulin estimates characterising the first or early phase of insulin secretion $(\Delta \mathrm{I} / \Delta \mathrm{G}$; $\left.\mathrm{I}_{10 \mathrm{~min}} / \mathrm{G}_{10 \mathrm{~min}} ; A \mathrm{AC}_{\text {insulin } 0 \rightarrow 10 \mathrm{~min}}\right)$. Therefore, these results suggest that during the early phase of insulin secretion the sensitivity of $\beta$-cells to glucose in castrated obese rabbits is probably still preserved but the secretory capacity of $\beta$-cells is disturbed, leading to the secretion of inadequate quantity of insulin which is unable to decrease blood glucose to the levels in non-obese rabbits (Georgiev et al., 2011). In chronically obese cats the first phase of insulin secretion was also decreased, while in humans insulin response to exogenous glucose might be normal, increased or reduced (Nelson et al., 1990; Festa et $a l ., 2008)$. The discrepancy of the obtained results could be at least partly due to the differences in the duration of the obesity period. However, the situation 
remains controversial as recent data in humans based on the comparison of surrogate markers (basal and from IVGTT) of insulin secretion and insulin sensitivity show that subjects with impaired glucose tolerance, before the clinical symptoms of diabetes may have more pronounced $\beta$ cell defects than previously estimated by homeostasis model assessment (Festa et al., 2008).

The well marked positive correlation between $\Delta \mathrm{I} / \Delta \mathrm{G}, \mathrm{I}_{10 \mathrm{~min}} / \mathrm{G}_{10 \mathrm{~min}}$ and $\mathrm{AUC}_{\text {insu- }}$ lin $0 \rightarrow 10$ min indicates that each of these indexes could be used for evaluation of first phase of insulin secretion. On the other hand, the strong correlation between fasting insulin and $\mathrm{HOMA}_{\beta \text {-cell }}$ indicates that increased insulin concentration at baseline might be considered as a simple and reliable marker not only for insulin resistance but also for $\beta$-cell compensation.

In non-castrated non-obese rabbits, lipid content in SMB muscle tended to be higher than in LL muscle. Therefore, more marked increase of lipid content in LL muscle after castration is probably due to its larger capacity for fat deposition.

The castrated rabbits exhibited typical signs of visceral type of obesity (greater body weight, body mass index and amount of intra-abdominal fat) (Georgiev et al., 2011) which is accompanied with marked accumulation of fat in skeletal muscles. In addition, intramuscular lipid content in SMB muscle correlated negatively with glucose elimination rate and positively with visceral fat and weight, indicating that in rabbits, abnormal ectopic fat deposition seems to play a primary pathogenic role in the obesity-induced impairment of insulin sensitivity.

There is increasing body of evidence that reactive oxygen species affect negatively insulin signalling pathway directly (stimulation of serine instead of tyrosine phosphorylation of IR and insulin receptor substrate 1 (IRS-1), increased IRS protein degradation, impaired signal transmission from phosphatidylinositol 3-kinase to protein kinase B, decreased GLUT-4 gene expression) and/or through suppression of adiponectin and peroxisome proliferatoractivated receptor gamma and induction of IL-6 and TNF- $\alpha$ gene expressions (Bashan et al., 2009). Nevertheless, a definitive estimation of the impact of dietary antioxidants on obesity-induced disorders such as insulin resistance and $\beta$ cell dysfunction is still lacking as the obtained results are inconvincing.

In our study the values of some of surrogate indexes of insulin resistance (basal insulin concentration, $\mathrm{I}_{0} / \mathrm{G}_{0}$ ratio, $\mathrm{HOMA}_{\text {ins. resist.) in Immunoprotect-treated }}$ rabbits were significantly lower while Bennett and QUICKI indexes were significantly higher than in castrated obese rabbits and did not differ from those in non-castrated non-obese rabbits. These results suggest that the supplementation of a combination of two antioxidants (vitamin $\mathrm{E}$ and d-limonene) can at least partly restore insulin sensitivity, confirming our previous results (Georgiev et al., 2009; 2011). Our findings correspond to the results of other authors, showing amelioration of oxidative stressinduced insulin resistance by exogenous administration of high doses of vitamin $\mathrm{E}$ (Manning et al., 2004; Houstis et al., 2006; Singh et al., 2008) and more recently of d-limonene in rats (Santiago et al., 2011).

The rabbits treated with Immunoprotect exhibited normalisation of $\beta$-cell function as the values of $\mathrm{HOMA}_{\beta}$ cell and $\mathrm{AUC}_{\text {insulin } 0 \rightarrow 60 \mathrm{~min}}$ were significantly lower than in castrated obese subjects and similar to those in controls. The 
Effect of antioxidant treatment on some indicators of obesity-induced changes in insulin sensitivity ...

favourable effect of Immunoprotect on insulin secretion is probably due to the ameliorated insulin action in treated animals, as there is a close interrelation between $\beta$-cell function and insulin sensitivity as shown in human studies (Bergman et al., 2002; Prentki \& Nolan, 2006). In addition, a direct beneficial effect of antioxidant treatment on $\beta$-cell function could be expected because of the lower local expression of antioxidant enzymes.

The protective effect of Immunoprotect treatment could be in part due to the powerful antioxidant properties of vitamin $\mathrm{E}$ and d-limonene, leading to rapid utilisation and degradation of fatty acids (Georgiev et al., 2009), thus inhibiting the lipogenesis and lipid accumulation in muscles. This is confirmed by our results from chemical muscle lipid analysis showing a marked decrease in response to Immunoprotect. Recently, d-limonene supplementation in high-fat diet-induced obesity in rats has been shown to decrease hepatic fat deposition throughout reduction of the activities of the key enzymes involved in the synthesis of fatty acids and triglycerides (Santiago et al., 2011).

In conclusion, we demonstrated that basal insulin concentration, $\mathrm{HOMA}_{\text {ins res, }}$ $\mathrm{I}_{0} / \mathrm{G}_{0}$ ratio, $\mathrm{HOMA}_{\beta}$ cell, $\mathrm{AUC}_{\text {insulin } 0 \rightarrow 60 \mathrm{~min}}$ and intramuscular lipid content in castrated obese rabbits were significantly higher while QUICKI and Bennett indices were significantly lower than in noncastrated non-obese rabbits. Surrogate indices are simple and reliable indicators of insulin sensitivity and $\beta$-cell function in rabbits as they were closely associated with markers of obesity and can be modified by antioxidant supplementation.

\section{ACKNOWLEDGEMENTS}

This study was supported by grant from the Ministry of Education and Science of Bulgaria and Trakia University Science Foundation, Stara Zagora, Bulgaria (grant no. 10/06). We would like to greatly acknowledge Prof. Zahari Raikov MD from the Medical Faculty of the Trakia University, Stara Zagora, Bulgaria for providing Immunoprotect and for his great and valuable scientific support, confidence and for the successful collaboration.

\section{REFERENCES}

Appleton, D. J., J. S. Rand \& G. D. Sunvold, 2005. Basal plasma insulin and homeostasis model assessment (HOMA) are indicators of insulin sensitivity in cats. Journal of Feline Medicine and Surgery, 7, 183-193.

Bashan, N., J. Kovsan, I. Kachko, H. Ovadia $\&$ A. Rudich, 2009. Positive and negative regulation of insulin signaling by reactive oxygen and nitrogen species. Physiological Reviews, 89, 27-71.

Bergman, R. N., M. Ader, K. Huecking \& G.VanCitters, 2002. Accurate assessment of b-cell function. The hyperbolic correction. Diabetes, 51, 212-220.

Boudina, S., S. Sena, C. Sloan, A. Tebbi, Y. H. Han, B. T. O'Neill, R. C. Cooksey, D. Jones, W. L. Holland, D. A. McClain \& E. D. Abel, 2012. Early mitochondrial adaptations in skeletal muscle to diet-induced obesity are strain dependent and determine oxidative stress and energy expenditure but not insulin sensitivity. Endocrinology, 153, 2677-2688.

Chen, H., G. Sullivan \& M. J. Quon, 2005. Assessing the predictive accuracy of QUICKI as a surrogate index for insulin sensitivity using a calibration model. Diabetes, 54, 1914-1925.

Ciampelli, M., F. Leoni, F. Cucinelli, S. Mancuso, S. Panunzi, A. De Gaetano \& A. Lanzone, 2005. Assessment of insulin sensitivity from measurements in the fas- 
ting state and during an oral glucose tolerance test in polycystic ovary syndrome and menopausal patients. The Journal of Clinical Endocrinology \& Metabolism, 90, 1398-1406.

Corcoran, M. P., S. Lamon-Fava \& R. A. Fielding, 2007. Skeletal muscle lipid deposition and insulin resistance: Effect of dietary fatty acids and exercise. American Journal of Clinical Nutrition, 85, 662-677.

Davis, R. L., C. L. Lavine, M. A. Arredondo, P. McMahon \& T. E. Tenner, 2002. Differential indicators of diabetes-induced oxidative stress in New Zealand white rabbits: role of dietary vitamin E supplementation. International Journal of Experimental Diabetes Research, 3, 185-192.

DeFronzo, R. A. \& D. Tripathy, 2009. Skeletal muscle insulin resistance is the primary defect in type 2 diabetes. Diabetes Care, 32, 157-163.

Dimitrova, S. \& I. P. Georgiev, 2007. Relative contribution of decreased insulin sensitivity to deterioration of glucose homeostasis. Bulgarian Journal of Veterinary Medicine, 10, 205-222.

Dimitrova, S. S., I. P. Georgiev, I. N. Kanelov, Y. I. Iliev, S. I. Tanev \& T. M. Georgieva, 2008. Intravenous glucose tolerance test and glucose kinetic parameters in rabbits. Bulgarian Journal of Veterinary Medicine, 11, 161-169.

Dokken, B. B., V. Saengsirisuwan, J. S. Kim, M. K. Teachey, E. J. Henriksen, 2008. Oxidative stress-induced insulin resistance in rat skeletal muscle: Role of glycogen synthase kinase-3. American Journal of Physiology - Endocrinology and Metabolism, 294, 615-621.

Festa, A., K. Williams, A. J. G. Hanley \& S. M. Hafner, 2008. $\beta$-cell dysfunction in subjects with impaired glucose tolerance and early type 2 diabetes. Comparison of surrogate markers with first-phase insulin secretion from an intravenous glucose tolerance test. Diabetes, 57, 1638-1644.

Franzini, L., D. Ardigo \& I. Zavaroni, 2008. Dietary antioxidants and glucose metabo- lism. Current Opinion in Clinical Nutrition and Metabolic Care, 11, 471-476.

Galic, S., J. S. Oakhill \& G. R. Steinberg, 2010. Adipose tissue as an endocrine organ. Molecular and Cellular Endicrinology, 316, 129-139.

Garcia-Diaz, D. F., J. Campion, A. V. Arellano, F. I. Milagro, M. J. Moreno-Aliaga \& J. A. Martinez, 2012. Fat intake leads to differential response of rat adipocytes to glucose, insulin and ascorbic acid. Experimental Biology and Medicine, 237, 407-416.

Georgiev, I. P., I. N. Kanelov, T. Mircheva Georgieva, V. Ivanov, S. Dimitrova, Y. Iliev, J. Nikolov, L. Lazarov \& A. Roussenov, 2009. Evaluation of insulin resistance in obese New Zealand white rabbits. Revue de Médicine Vétérinaire, 160, 335-340.

Georgiev, I. P., T. Mircheva Georgieva, V. Ivanov, S. Dimitrova, I. Kanelov, T. Vlaykova, S. Tanev, D. Zaprianova, E. Dichlianova, G. Penchev, L. Lazarov, E. Vachkova \& A. Roussenov, 2011. Effects of castration-induced visceral obesity and antioxidant treatment on lipid profile and insulin sensitivity in New Zealand white rabbits. Research in Veterinary Science, 90, 196-204.

Gerich, J. E., 2003. Contribution of insulin resistance and insulin-secretory defects to the pathogenesis of type 2 diabetes mellitus. Mayo Clinic Proceedings, 78, 447-456.

Giacca, A., C. Xiao, A. I. Oprescu, A. C. Carpentier \& G. F. Lewis, 2010. Lipidinduced pancreatic $\beta$-cell dysfunction: Focus on in vivo studies. American Journal of Physiology - Endocrinology and Metabolism, 300, 255-262.

Gil-Campos, M., C. M. Aguilera, M. C. Ramirez-Tortosa, K. Canete \& A. Gil, 2010. Fasting and postprandial relationships among leptin, ghrelin and insulin in prepubertal obese children. Clinical Nutrition, 29, 54-59.

Gondret, F., J. F. Hocquette \& P. Herpin, 2004. Age-related relationships between muscle fat content and metabolic traits in 
Effect of antioxidant treatment on some indicators of obesity-induced changes in insulin sensitivity ...

growing rabbits. Reproduction Nutrition Development, 44, 1-16.

Haugaard, S. B., H. Mu, A. Vaag \& S. Madsbad, 2009. Intramyocellular triglyceride content in man, influence of sex, obesity and glycaemic control. European Journal of Endocrionology, 161, 57-64.

Henriksen, E. J., 2010. Dysregulation of glycogen synthase kinase-3 in skeletal muscle and the etiology of insulin resistance and type 2 diabetes. Current Diabetes Reviews, 6, 285-293.

Henriksen, E. J. \& B. B. Dokken, 2006. Role of glycogen synthase kinase-3 in insulin resistance and type 2 diabetes. Current Drug Targets, 7, 1435-1441.

Houstis, N., E. D. Rosen \& E. S. Lander, 2006. Reactive oxygen species have a causal role in multiple forms of insulin resistance. Nature, 440, 944-948.

Ibrahim, M. M., 2010. Subcutaneus and visceral adipose tissue: Structural and functional differences. Obesity Reviews, 11, 11-18.

Irvine, A., R. Butterwick, T. Watson, D. J. Millward \& L. M. Morgan, 2002. Dietary supplementation with (n-3) polyunsaturated fatty acids does not affect insulin sensitivity in healthy Labrador retriever dogs. Journal of Nutrition, 132, 1709-1710.

Kahn, S. E., 2003. The relative contributions of insulin resistance and beta-cell dysfunction to the pathophysiology of type 2 diabetes. Diabetologia, 46, 3-19.

Kainuma, M., M. Fujimoto, N. Sekiya, K. Tsuneyama, C. Cheng, Y. Takano, K. Terasawa \& Y. Shimada, 2006. Cholesterolfed rabbits as a unique model of nonalcoholic, nonobese non-insulin-resistant fatty liver disease with characteristic fibrosis. Journal of Gastroenterology, 41, 971-980.

Kaneto, H., D. Kawamori, T.A. Matsuoka, Y. Kajimoto \& Y. Yamasaki, 2005. Oxidative stress and pancreatic beta-cell dysfunction. American Journal of Therapeutics, 12, 529-533.
Kawai, T., T. Ito, K. Ohwada, Y. Mera, M. Matsushita \& H. Tomoike, 2006. Hereditary postprandial hypertriglyceridemic rabbit exhibits insulin resistance and central obesity: A novel model of metabolic syndrome. Arteriosclerosis Thrombosis and Vascular Biology, 26, 27522757.

Kitajima, S., M. Morimoto, E. Liu, T. Koike, Y. Higaki, Y. Taura, K. Mamba, K. Itamoto, T. Watanabe, K. Tsutsumi, N. Yamada \& J. Fan, 2004. Overexpression of lipoprotein lipase improves insulin resistance induced by a high-fat diet in transgenic rabbits. Diabetologia, 47, 1202-1209.

Larson, B., D. Lawler, E. Spitznagel \& R. Kealy, 2003. Improved glucose tolerance with lifetime diet restriction favorably affects disease and survival in dogs. Journal of Nutrition, 133, 2887-2892.

Lewis, G. F., A. Carpentier, K. Adeli \& A. Giacca, 2002. Disordered fat storage and mobilization in the pathogenesis of insulin resistance and type 2 diabetes. Endocrine Reviews, 23, 201-229.

Lin, L., W. Pang, K. Chen, F. Wang, J. Gengler, Y. Sun \& Q. Tong, 2012. Adipocyte expression of PU.1 transcription factor causes insulin resistance through up-regulation of inflammatory cytokine gene expression and ROS production. American Journal of Physiology - Endocrinology and Metabolism, 302, E1550E1559.

Liu, E., S. Kitajima, S. Higaki, M. Y. Morimoto, H. Sun, T. Watanabe, N. Yamada \& J. Fan, 2005. High lipoprotein lipase activity increases insulin sensitivity in transgenic rabbits. Metabolism, 54, 132 138.

Lu, H., V. Koshkin, E. M. Allister, A. V. Gyulkhandanyan \& M. B. Wheeler, 2010. Molecular and metabolic evidence for mitochondrial defects associated with $\beta$ cell dysfunction in a mouse model of type 2 diabetes. Diabetes, 59, 448-459. 
Manning, P. G., W. H. F. Sutherland, R. J. Walker, S. M. Williams, S. A. De Jong, A. R. Ryalls \& E. A. Berry, 2004. Effect of high-dose vitamin $\mathrm{E}$ on insulin resistance and associated parameters in overweight subjects. Diabetes Care, 27, 2166-2171.

Martinez-Hervas, S., C. Argente, J. GarciaJodar, A. Priego, J. T. Real, A. Carratala, R. Carmena \& J. F. Ascaso, 2011. Misclassification of subjects with insulin resistance and associated cardiovascular risk factors by homeostasis model assessment index. Utility of a postprandial method based on oral glucose tolerance test. Metabolism, 60, 740-746.

Martins, A. R., R. T. Nachbar, R. Gorjao, M. A. Vinolo, W. T. Festuccia, R. H. Lambertucci, M. F. Cury-Boaventura, L. R. Silveira, R. Curi \& S. M. Hirabara, 2012. Mechanisms underlying skeletal muscle insulin resistance induced by fatty acids: importance of the mitochondrial function. Lipids in Health and Disease, 23, 11-30.

Matsuzawa-Nagata, N., T. Takamura, H. Ando, S. Nakamura, S. Kurita, H., Misu, T. Ota, M. Yokoyama, M. Honda, K. Miyamoto \& S. Kaneko, 2008. Increased oxidative stress precedes the onset of highfat diet-induced insulin resistance and obesity. Metabolism, 57, 1071-1077.

Mattheeuws, D., R. Rottiers, J. J. Kaneko \& A. Vermeulen, 1984. Diabetes mellitus in dogs: Relationship of obesity to glucose tolerance and insulin response. American Journal of Veterinary Research, 45, 98103.

Morino, K., K. F. Petersen \& G. I. Shulman, 2006. Molecular mechanisms of insulin resistance in humans and their potential links with mitochondrial dysfunction. Diabetes, 55, 9-15.

Muniyappa, R., H. Chen, R. H. Muzumdar, F. H. Einstein, X. Yan, L. Q. Yue, N. Barzilai \& M. J. Quon, 2009. Comparison between surrogate indexes of insulin sensitivity/resistance and hyperinsulenimic euglycemic clamp estimates in rats. American Journal of Physiology-Endocrinology and Metabolism, 297, 1023-1029.
Muoio, D. M., 2010. Intramuscular triacylglycerol and insulin resistance: Guilty as charged or wrongly accused? Biochimica et Biophysica Acta, 1801, 281-288.

Nelson, R. W., C. A. Himsel, E. C. Feldman \& G. D. Bottoms, 1990. Glucose tolerance and insulin response in normal-weight and obese cats. American Journal of Veterinary Research, 51, 1357-1362.

Opara, E. C., 2004. Role of oxidative stress in the etiology of type 2 diabetes and the effect of antioxidant supplementation on glycemic control. Journal of Investigative Medicine, 52, 19-23.

Poitout, V. \& R. P. Robertson, 2008. Glucolipotoxicity: Fuel excess and beta-cell dysfunction. Endocrine Reviews, 29, 351-366.

Prentki, M. \& C. J. Nolan, 2006. Islet beta cell failure in type 2 diabetes. Journal of Clinical Investigation, 116, 1802-1812.

Roberts, C. K. \& K. K. Sindhu, 2009. Oxidative stress and metabolic syndrome. Life Sciences, 84, 705-712.

Robertson, R. P., 2004. Chronic oxidative stress as a central mechanism for glucose toxicity in pancreatic islet beta cells in diabetes. Journal of Biological Chemistry, 279, 42351-42354.

Saltiel, A. R., 2001. New perspectives into the molecular pathogenesis and treatment of type 2 diabetes. Cell, 104, 517-529.

Samuel, V.T., K.F. Petersen \& G. I. Shulman, 2010. Lipid-induced insulin resistance: Unravelling the mechanism. Lancet, 375, 2267-2277.

Santiago, J., J. Jayachitra, M. Shenbagam \& N. Nalini, 2011. Dietary d-limonene alleviates insulin resistance and oxidative stress-induced liver injury in high-fat diet and L-NAME-treated rats. European Journal of Nutrition, 51, 57-68.

Singh, I., A. L. Carey, N. Watson, M. A. Febbraio \& J. A. Hawley, 2008. Oxidative stress-induced insulin resistance in skeletal muscle cells is ameliorated by gammatocopherol treatment. European Journal of Nutrition, 47, 387-392. 
Effect of antioxidant treatment on some indicators of obesity-induced changes in insulin sensitivity ...

Slavov, E., I. Penchev Georgiev, P. Dzhelebov, I. Kanelov, M. Andonova, T. Mircheva Georgieva \& S. Dimitrova, 2010. High-fat feeding and Staphylococcus intermedius infection impair beta cell function and insulin sensitivity in mongrel dogs. Veterinary Research Communications, 34, 205-215.

Slavov, E. \& P. Dzhelebov, 2010. Basic endocrine products of adipose tissue - a review. Bulgarian Journal of Veterinary Medicine, 13, 199-210.

Thiess, S., C. Becskei, K. Tomsa, T. A. Lutz \& M. Wanner, 2004. Effects of high carbohydrate and high fat diet on plasma metabolite levels and on i.v. glucose tolerance test in intact and neutered male cats. Journal of Feline Medicine and Surgery, 6, 207-218.

Tripathy, D., P. Almgren, T. Tuomi \& L. Groop, 2004. Contribution of insulinstimulated glucose uptake and basal hepatic insulin sensitivity to surrogate measures of insulin sensitivity. Diabetes Care, 27, 2204-2210.

Valdecantos, M. P., P. Perez-Matute \& J. A. Martinez, 2009. Obesity and oxidative stress: Role of antioxidant supplementation. Revista de investigación clinica, 61, 127-139.

Verkest, K. R., L. M. Fleeman, J. S. Rand \& J. M. Morton, 2005. Insulin sensitivity is halved and fasting insulin concentration increased four times in spontaneously obese dogs. In: 2005 ACVIM: Abstracts published in the Journal of Veterinary Internal Medicine. ACVIM Forum, Annual Conference of the American College of Veterinary Internal Medicine, Baltimore, pp. 424-425.

Verkest, K R., L. M. Fleeman, J. M. Morton, K. Ishioka \& J. S. Rand, 2011. Compensation for obesity-induced insulin resistance in dogs: Assessment of the effects of leptin, adiponectin, and glucagon-like peptide-1 using path analysis. Domestic Animal Endocrinology, 41, 24-34.
Wallace, T., J. Levy \& D. Matthews, 2004. Use and abuse of HOMA modeling. Diabetes Care, 27, 1487-1495.

Waqar, A. B., T. Koike, Y. Yu, T. Inoue, T. Aoki, E. Liu \& J. Fan, 2010. High-fat diet without excess calories can induce metabolic disorders and enhances atherosclerosis in rabbits. Atherosclerosis, 213, 148155.

Weir, G. \& S. Bonner-Weir, 2004. Five stages of evolving $\beta$-cell dysfunction during progression to diabetes. Diabetes, 53, 16-21.

Weiss, R., 2007. Fat distribution and storage: How much, where and how? European Journal of Endocrinology, 157, 39-45.

Zhao, S., Y. Chu, C. Zhang, Y. Lin, K. Xu, P. Yang, J. Fan \& E. Liu, 2007. Diet-induced central obesity and insulin resistance in rabbits. Journal of Animal Physiology and Animal Nutrition (Berlin), 92, 105-111.

Zheng, H., C. Zhang, Y. Wang, Y. Lin, P. Yang, Q. Yu, J. Fan \& E. Liu, 2009. Fat and cholesterol diet induced lipid metabolic disorders and insulin resistance in rabbit. Experimental and Clinical Endocrinology and Diabetes, 117, 400-405.

Paper received 11.12.2014; accepted for publication 22.01.2015

\section{Correspondence:}

Prof. Ivan Penchev Georgiev

Department of Pharmacology, Animal

Physiology and Physiological Chemistry,

Faculty of Veterinary Medicine,

Trakia University,

6000, Stara Zagora, Bulgaria tel: 00359887064791

e-mail: ivanpenchev@uni-sz.bg 